\title{
How companies evaluate the ROI of social media marketing programmes: insights from $B 2 B$ and B2C
}

\author{
Susana Costa e Silva \\ Católica Porto Business School, Universidade Católica Portuguesa, Porto, Portugal \\ Paulo Alexandre Oliveira Duarte \\ NECE- Research Unit in Business Sciences, University of Beira Interior, Covilhã, Portugal, and \\ Sara Resende Almeida \\ Católica Porto Business School, Universidade Católica Portuguesa, Porto, Portugal
}

\begin{abstract}
Purpose - The purpose of this study is to understand and compare how business-to-business (B2B) and business-to-consumer (B2C) companies evaluate the return on investment (ROI) on their social media marketing (SMM) programmes and how the investment is handled in these type of marketing programmes.

Design/methodology/approach - A mixed-methods approach involving multiple cases and a survey was used. Data were collected from personal interviews with eight professionals responsible for SMM management, from four B2B and four B2C companies, complemented with responses to a web-based survey by the other 28 companies' marketing managers.

Findings - The results show that there are some differences between B2B and B2C companies regarding SMM evaluation and investment but in general marketing managers for both types of firms use simple metrics to evaluate their SMM programmes. The main measures used relate to awareness, engagement and reach and most of the metrics identified are interaction-related.

Research limitations/implications - Given the complex and sensitive nature of the subject, more research is needed focussed on providing additional evidence from a larger sample of B2B and B2C organizations to allow the extension of the finding to the population as the nonprobabilistic nature and size of the current sample impose that the findings should be interpreted carefully. Future research should focus on understanding what the firm's characteristics predict the importance and level of effort placed in SMM and the barriers to ROI measurement in SMM programmes, especially in B2B firms.

Practical implications - The current findings confirm that the topic of SMM ROI evaluation is not a priority for B2C or B2B companies. There is a need for an update of their online marketing strategy, namely, on budget definition and allocation. Furthermore, companies should increase the autonomy of SM managers, as they are dependent from marketing managers and hire specialized professionals devoted to SMM in both B2C and B2B companies.

Originality/value - The findings of this study contribute to improve the understanding of the evaluation of SMM and to extend the literature on the subject. It also provides a relevant advance into the assessment and understanding on the measures used to evaluate the effectiveness of SMM programmes by offering a comparison on how B2B and B2C use metrics and allocate resources to the SMM management.
\end{abstract}

Keywords Social media marketing, B2B, B2C, Return on investment, Digital marketing

Paper type Research paper

\section{Introduction}

About a third of internet users use social media (SM) and according to Statista(2017) projections, in 2021 there will be around 3.01 billion SM users around the world, up from 2.46 billion in 2017, representing more than four times the population of Europe. Although SM are considerably different from other media, they are becoming an ever more important part of an organization's media mix (Hoffman and Fodor,

The current issue and full text archive of this journal is available on Emerald Insight at: https://www.emerald.com/insight/0885-8624.htm

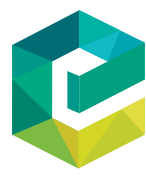

Journal of Business \& Industrial Marketing 35/12 (2020) 2097-2110

(C) Emerald Publishing Limited [ISSN 0885-8624] [DOI 10.1108/JBIM-06-2019-0291]
2010; Hoffman and Novak, 2012). SM allows companies to reach consumers, communicate with them and assess their communication, but new strategic and tactical marketing approaches must be developed to deal with the singularities of this type of media (Hennig-Thurau et al., 2010; Wang et al.,

\footnotetext{
The authors would like to thank to NECE - Research Unit in Business Sciences funded by the Multiannual Funding Programme of R\&D Centres of FCT - Fundação para a Ciência e a Tecnologia, under the project UID/ GES/04630/2019 and to CEGE - Research Centre in Management and Economics, funded by the Multiannual Funding Programme of R\&D Centres of FCT - Fundação para a Ciência e a Tecnologia, under the project UIDB/00731/2020.
}

Received 14 June 2019

Revised 11 September 2019

27 December 2019

2 April 2020

Accepted 2 April 2020 
2017). In contrast to other media, SM platforms are dynamic, interconnected, interactive and sometimes beyond the control of the organization (Peters et al., 2013). Differently from other digital advertising tools, SM platforms are these that allow precise targeting of an audience, provide the ability to interactively exchange information, promote increased interaction and easy sharing of content, either user-generated or other provided by third parties (Carr and Hayes, 2015; Huotari et al., 2015; Voorveld et al., 2018).

Given the competitiveness of current markets and the constraints imposed on firms, businesses need to guarantee that they get a return on their investments and companies are struggling to prove the value of their investments in social media marketing (SMM) programmes (Fisher, 2009; Headley, 2015). According to the 2016 SMM industry report, a significant $90 \%$ of marketers said that SM was important to their business, but just $41 \%$ agreed they were able to measure their social activities as it introduced substantial changes to the communication between consumers and organizations. Furthermore, a significant $86 \%$ of marketers want to know how to measure their return on investment (ROI) for SM activities (Stelzner, 2016). How much companies spend and how long they will continue to spend it will be determined by the effectiveness of SM. This means that firms will adopt more SM initiatives if they provide enough ROI (Kaske et al., 2012). For many marketing managers, experience tells them that SMM is important and as a result, they struggle to identify the most effective strategies to reach and engage with their public in SM (Zhang and Li, 2019). However, a lack of ability, combined with uncertainty about what metrics should be used and the frequent pressure of top management teams wanting to see numbers has made the measurement of social media marketing return on investment (SMM-ROI) one of the biggest challenges for the adoption of SMM strategies by organizations (Fisher, 2009; Hoffman and Fodor, 2010; Kietzmann et al., 2011).

Business-to-business (B2B) and business-to-consumer (B2C) companies target distinct markets and their clients hold different behaviours regarding the use of SM, therefore companies are expected to craft the approach to the investment, use and evaluation of SM platforms, as SMM is not as generalized in the (B2B) market as it is in the B2C market (Bernard, 2016; Lashgari et al., 2018; Wang et al., 2017). For example, Wang et al.(2017) report that in the B2B context the networking capability of SM is highly emphasized and the user-generated content is underrated and it highlights also the fact that SM communities may have a different role in $\mathrm{B} 2 \mathrm{~B}$ and $\mathrm{B} 2 \mathrm{C}$ contexts. Furthermore, Bolat et al.(2016) suggest that the investigation made in B2B SMM is decidedly influenced by B2C marketing research. As models from B2C SMM are being imported to the B2B context this may well explain the small number differences. Based on this evidence, it is reasonable to assume that $\mathrm{B} 2 \mathrm{C}$ and $\mathrm{B} 2 \mathrm{~B}$ companies may use different metrics and assign distinct weights to each metric. Therefore, it is important to identify and understand the differences in SMM between B2B and B2C companies (Iankova et al., 2019). Such understanding of the similarities and differences between the two types pf companies could be of interest not only for both types of companies benchmarking their strategies and practices but also for researchers to support futures research, namely, to answer the "why", which is out of the scope for the current investigation. Thus, the current article concentrates on the "how" and has as the main objective to provide a comprehensive overview on how B2B and B2C companies assess the investments in SMM campaigns from a theoretical and an empirical point of view. Previous research on the adoption of SM in B2B has mostly focussed on the goal and impact of SM adoption to improve communication (Lashgari et al., 2018), but largely avoided the topic of ROI. Therefore, the specific objectives are as follows:

- to compile and describe the existing measures of ROI for SMM programmes based on previous research;

- to investigate how companies define and allocate budgets to SMM campaigns;

- to understand the measures used by SM managers to evaluate these programmes; and

- to compare B2C and B2B perception on the of SM.

This study adds to the existing literature by providing a holistic and thorough view of the practices of SMM evaluation and by contrasting the reality of both $\mathrm{B} 2 \mathrm{C}$ and $\mathrm{B} 2 \mathrm{~B}$ companies.

\section{The use of social media marketing in business- to-business and business-to-consumer companies}

SMM understood as "the use of SM to facilitate exchanges between consumers and organizations" (Tuten and Solomon, 2014 , p. 37) is a valuable tool for marketers to create value for stakeholders as it provides an economical way to reach, to interact and to engage with different audiences both internally and externally and with clients at different points in the buying process (Andersson and Wikström, 2017). Organizations of all sizes and types are increasingly incorporating SMM into their marketing activities to take advantage of the benefits and opportunities they offer in attracting new customers and maintaining a close relationship with existing ones (Atanassova and Clark, 2015; Siamagka et al., 2015). This is true for both $\mathrm{B} 2 \mathrm{C}$ and $\mathrm{B} 2 \mathrm{~B}$ companies. However, in B2B environments many decision-makers perceive the presence on SM to be less important than B2C companies, as they consider that SMM cannot sustain their marketing goals (Michaelidou et al., 2011).

Furthermore, in some cases, SMM is seen even as unnecessary for B2B businesses (Jussila et al., 2014). Nevertheless, the perspective has been changing and SMM adoption has gained increased importance and recognition (Bocconcelli et al., 2017; Keinänen and Kuivalainen, 2015; Zhang and Li, 2019). Despite the controversy, research by Siamagka et al. (2015) discloses that many innovative marketers in the UK intend to increase their investment in SMM, meaning that its value is gradually starting to be recognized (Shaltoni, 2017) and Lacka and Chong (2016) argue that the benefits of SMM for B2C firms are also valid for B2B companies. In fact, according to Michaelidou et al. (2011) and Siamagka et al. (2015), B2B firms using SM platforms fail in measuring the effectiveness of their presence as they just focus on interaction data such as the number of followers or comments. This lack of knowledge and skills to properly evaluate the benefits of the SM presence by B2B companies may explain the lower importance devoted to SMM by them. 


\subsection{Budget allocation in social media marketing programmes}

Unlike traditional media programmes that are, in most cases, expensive, SMM strategy does not require a huge budget. According to Weinberg and Pehlivan (2011), there is no standard formula for determining how much a firm should invest in SMM or how the budget should be allocated among owned (e.g. firm's website), free (e.g. Facebook page) and paid solutions (e.g. paid advertising campaigns) (Hanna et al., 2011). The decision must consider the firm's characteristics and resources such as internal digital infrastructure, human resources, knowledge, media choices and target consumers' preferences to select the best investment decisions. According to Wang et al. (2017) these dimensions constitute the firm's SM capability and could be grouped in four levels, the:

1 technological level;

2 operational level;

3 managed level; and

4 strategic level;

which must be aligned with each other to provide the maximum value from the use of SM to develop marketing activities.

Despite the challenges surrounding the choices on how much to spend and where to spend, being out of SM does not seem a wise decision. According to Statista(2020), SM advertising expenditure will continue to grow worldwide and is expected to show a Compound Annual Growth Rate (CAGR 2020-2023) of $7.0 \%$, resulting in the market value of US $\$ 125,482 \mathrm{~m}$ by 2023 (Figure 1).

\subsection{Measures of return on investment to evaluate social media marketing programmes}

SMM-ROI refers to what a company is getting back from the time, money and resources it is investing in SMM (Jackson, 2017). It is a measure of profitability defined as the net proceeds from the investment in SMM over its costs (Tuten, 2008). SMM and the ability to measure its ROI are being hotly debated (Bartholomew, 2009, 2010; Fisher, 2009; Murdough, 2009; Nair, 2011). While most firms understand the need for SM presence as part of their marketing strategy, marketers must measure the impact of a two-way conversation on their brands to make the right strategic and tactical decisions (Fieler, 2017; Powell et al., 2011). However, measuring the ROI of an SMM programme remains a challenge for companies and, despite the increasing use of SM, often as a supplemental promotional tool, many organizations do not have an idea of how to measure its performance (Atanassova and Clark, 2015; Headley, 2015). Additionally, companies have to deal with the dual nature of SM; the owned SM, which is controlled by the company and the earned SM, representing the activities that are neither directly generated nor controlled by the company (Colicev et al., 2018).

Figure 1 Outlook for SM advertising expenditure worldwide from 2017 to 2023

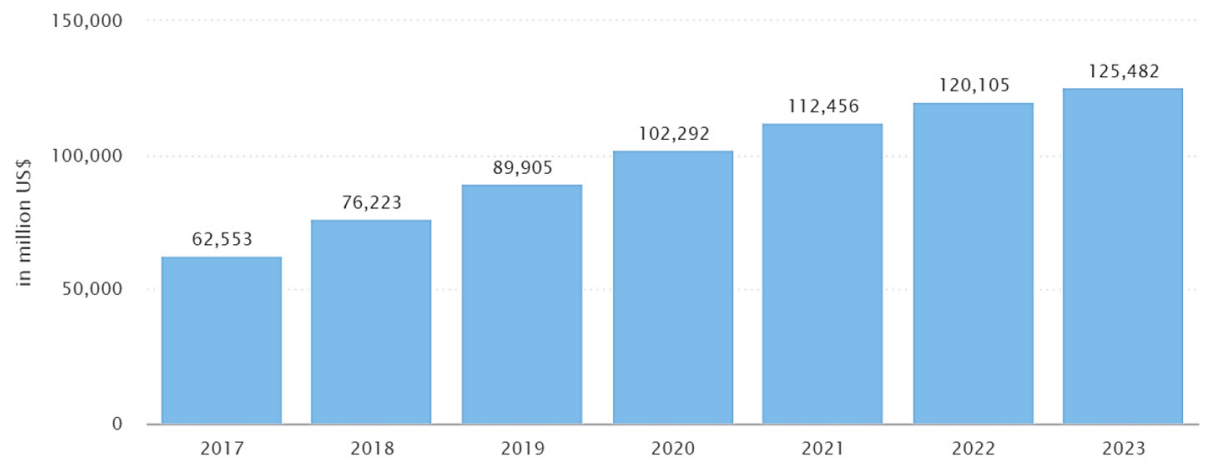

Source: Statista (2020)

Table 1 Points of view on SM ROI measurement

\begin{tabular}{|c|c|}
\hline Point of view & Author \\
\hline $\begin{array}{l}\text { SMM-ROI cannot be measured or is nearly impossible (attempts to } \\
\text { measure are folly or will be fraught with major issues) }\end{array}$ & Filisko (2011); Dorflinger (2011), Zheng et al. (2010) \\
\hline $\begin{array}{l}\text { SMM-ROI can be measured but should be defined and measured in } \\
\text { a certain way }\end{array}$ & $\begin{array}{l}\text { Kumar and Mirchandaniand (2012), Paul et al. (2012); Hoffman and Fodor (2010), } \\
\text { Owyang (2010); Mangiuc (2009) }\end{array}$ \\
\hline SMM ROI can only be measured in financial terms & Kaske et al. (2012), Turner (2010); Blanchard (2009) \\
\hline $\begin{array}{l}\text { SMM-ROI can be measured as a part of a larger, contextual } \\
\text { framework or system }\end{array}$ & $\begin{array}{l}\text { Peters et al. (2013), Gilfoil and Jobs (2012); Nair (2011), Bartholomew (2011); } \\
\text { Blanchard (2011), Ray et al. (2010); Lake (2009), Murdough (2009) }\end{array}$ \\
\hline SMM-ROI can be readily measured without much difficulty & $\begin{array}{l}\text { Fieler (2017); Coleman and Heriot (2014), Vlachvei and Notta (2015); Hall and } \\
\text { Hume (2011), Campbell (2011); Gillin (2010), Bughin and Chui (2010) }\end{array}$ \\
\hline
\end{tabular}


Altogether, the challenge when it comes to SMM is the qualitative, viral and pervasive nature of some outcomes such as image improvement, brand engagement or brand equity (Tuten, 2008). Table 1 presents a summary of the debate regarding the measure of SMM-ROI, which updates the systematization by Gilfoil and Jobs (2012).

Based on the current update it can be stated that the original conclusion by Gilfoil and Jobs (2012) remains, pointing out to the fact that there is no agreement on the ability to measure the return of SMM investments. It stands out that there is no single measure for SMM-ROI, but rather a range of performance indicators, metrics and tools that can help marketing managers to evaluate the success of their SMM programmes (Etlinger and $\mathrm{Li}, 2011$ ).

\section{Social media marketing performance indicators, metrics and tools}

The measurement of SM value is an under-researched area (Wang et al., 2017). To effectively assess SMM programmes it is necessary to develop a strategy and define its objectives before launching (Weinberg and Pehlivan, 2011). According to Headley (2015), there are two main challenges when setting goals for SMM campaigns, which can influence the effectiveness of the measurement of ROI. These are as follows:

1 defining SMM's goals consistent across all the company's departments; and

2 align the SMM strategy with the overall business strategy.

Metrics are units of measurement and indicators of the effectiveness of a digital marketing strategy (Stokes, 2013). They are used with the objective of understanding, controlling and improving marketing activities. Metrics allow companies to evaluate the perceived effectiveness of marketing actions, using quantitative indicators that are easy to read, compare and understand. Metrics that are central to evaluate the organization's success are considered key performance indicators (KPI). To be a KPI, the metric must reflect how well an organization's objectives are being served (Sterne, 2010). In most cases, a single metric can be insufficient to describe all relevant aspects of a goal, so a set of metrics is usually required to guide managers in the evaluation of the whole activity and these are usually portrayed in a dashboard (Pauwels et al., 2009; Peters et al., 2013).

The ROI of SMM can be measured in financial and nonfinancial ways. However, many benefits delivered by SMM are not easily measured in terms of money but through nonfinancial measures (Jackson, 2017). To measure the ROI in a financial way it is necessary to know how much money is going into the company's SMM effort and how much money the company is getting in return, specifically from the SMM investment, which is not easy to determine. When brands sell directly to online consumers they can explicitly link SMM campaigns to financial outcomes, but when brands do not sell directly to online consumers it is difficult to understand whether or not the revenues actually come from SMM campaigns (Ray et al., 2010).

To understand the metrics and tools available to SMM managers for evaluating the efficacy of the SMM campaigns, Table 2 presents a systematization of the financial and nonfinancial metrics and tools available according to the literature.
Based on the analysis of the metrics identified for each type of objective (Table 2) it becomes clear that non-financial metrics are mainly intended to measure the exposure, the reach, the level and depth of the interaction of SM users with the company, as well as how its messages spread among them. The performance of these actions may not directly generate sales but they are the front door for the sales funnel (Holloman, 2014). A company benefiting from increased exposure enhances and strengthens the associations in customers' minds, which may result in increased sales (Hewett et al., 2016; Hoffman and Fodor, 2010). Likewise, the Word-of-mouth or amplification effect, measures the spread of the company's message (the viral effect), which may result in additional visibility, the increase in potential customers, improved satisfaction and repeat purchasing behaviour (Coleman and Heriot, 2014; Vlachvei and Notta, 2015).

Regarding financial indicators, the major one is revenue. It is calculated by subtracting the costs from the earnings (Culnan et al., 2010; Turner and Shah, 2014; Vlachvei and Notta, 2015). To evaluate the revenue and the outcome, companies need to have the technological and operational capability to track the sales and the costs associated with each SMM action individually (Cytron, 2013).

\section{Methods}

To get a comprehensive understanding of the importance of SMM, the budget allocation, the ROI measurement process and the measures used by companies, this research adopted a mixed-methods methodology in two stages.

\subsection{First stage}

The method selected for the first stage was the case study research method. This method involves in-depth studies based on data collected from Interviews, field observations or review of documents of one or a small number of cases (Zeithaml et al., 2020). Therefore, the current study is of qualitative nature and consists of multiple-cases analysis (Simons, 2009; Thomas, 2015; Yin, 2018). A case is a specific phenomenon or entity, which represents complex realities that have to be studied in its own particular situation (Stake, 2006). In the current research design of each company is considered a "case" that was individually analysis throughout the interview in its specific context (B2B or B2C). As multiple cases were individually analysed in their context and then compared to assess the interactions within and between contexts, the approach can be classified as an explorative and descriptive multi-case design (Yin, 2018). For the current research, the multiple-case design is preferred as they offer several advantages, as it offers the ability not only to explore the particularities of each case but also to compare the findings from all cases and as it includes more data the findings are considered more convincing and the studies are regarded as being more robust (Yin, 2018). Considering the study objectives the Type 3 - multi-case (holistic) design was selected as it seems the most appropriate to contrast and reveal the differences and similarities among the cases and to analyse the data both within each situation and across situations (Baxter and Jack, 2008; Yin, 2018). A set of eight cases, four B2B and four 
Table 2 SMM performance indicators, metrics and tools

\begin{tabular}{|c|c|c|}
\hline Objectives & Metrics & Tools \\
\hline \multicolumn{3}{|l|}{ Non-financial measures } \\
\hline Awareness & Visits (unique visitors, frequency of visits, depth of visit and time spent in a visit per user); the & Web analytic tools; \\
\hline Brand building & $\begin{array}{l}\text { number of likes; the number of members/fans; the number of impressions; the number of times } \\
\text { bookmarked; organic search; search ranking; the number of posts about the brand; the number } \\
\text { of tags; the number of reviews/ratings and valence }(+I-) \text {; number and valence of other users' } \\
\text { responses to reviews }(+I-) \text {; the number of wish list adds; the number of times product/brand } \\
\text { included in users' lists; and app installations }\end{array}$ & $\begin{array}{l}\text { SM platforms specific } \\
\text { analytics; and } \\
\text { surveys }\end{array}$ \\
\hline Engagement & Visits (unique visitors, frequency of visits, depth of visit and time spent in a visit per user); & \\
\hline Community building & $\begin{array}{l}\text { number of comments; link clicks; number of members/fans; number of page views; number of } \\
\text { likes; views (videos, ads and rich images); amount of user-generated content; average length of } \\
\text { time on site; number of responses to polls, contests, surveys; number of replies; shares, } \\
\text { participation; number of reviews; length of reviews; relevance of reviews; valence of other } \\
\text { users' ratings of reviews; number of wish list adds; overall number of reviewer rating scores } \\
\text { entered; average reviewer rating score; impressions-to-interactions ratio; downloads; alerts } \\
\text { subscriptions; bookmarks; favourites; feedback; forward to a friend; groups; install widget; } \\
\text { messaging (onsite); profile personalization; report spam/abuse; tagging (user-generated } \\
\text { metadata); testimonials; time spent on key pages; time spent onsite; total contributors (and \% } \\
\text { active contributors); uploads (add articles, links, images, videos); widgets (number of new } \\
\text { widgets users/embedded widgets); and items saved to the Wishlist }\end{array}$ & \\
\hline Word of mouth & Number of references/mentions in the same media and other media (online/offline); the & \\
\hline Reach & number of shares; the number of reviews; valence of reviews; number and valence of other & \\
\hline Amplification & $\begin{array}{l}\text { users' responses to reviews (+I-); the number of references to reviews in other sites; the } \\
\text { number of visits to review site page; the number of times a product/brand is included in users' } \\
\text { lists; frequency of appearances in the timeline of friends; the number of posts on the wall; the } \\
\text { number of responses to friend referral invites; the number of embeddings; the number of } \\
\text { incoming links; and interaction rate (percentage of people who saw a post and liked, shared, } \\
\text { clicked or commented it) }\end{array}$ & \\
\hline $\begin{array}{l}\text { Customer satisfaction } \\
\text { Influence } \\
\text { Loyalty }\end{array}$ & $\begin{array}{l}\text { Likes and reactions; the number of customer complaints and response; feelings about the } \\
\text { brand/firm; and share of voice }\end{array}$ & $\begin{array}{l}\text { Social intelligence tools; } \\
\text { and } \\
\text { surveys }\end{array}$ \\
\hline \multicolumn{3}{|l|}{ Financial measures } \\
\hline Revenue & $\begin{array}{l}\text { Sales through SM platforms; sales instigated by SM communications; revenue per customer; } \\
\text { repeat purchase rate; average customer lifetime; cost savings; reduced advertising costs; } \\
\text { reduced customer retention cost; and reduced cost of managing customer complains }\end{array}$ & $\begin{array}{l}\text { Web analytics; } \\
\text { e-mail; } \\
\text { website; and } \\
\text { point-of-purchase } \\
\text { surveys }\end{array}$ \\
\hline Outcomes & \multicolumn{2}{|c|}{$\begin{array}{l}\text { Measures that act as a proxy for desired outcomes, for example, the likelihood of future purchase by a user engaged with the } \\
\text { company's brand through a specific SM application or the reach of a specific word-of-mouth element and subsequent } \\
\text { conversion to future sales (Hoffman and Fodor, 2010) }\end{array}$} \\
\hline
\end{tabular}

B2C were selected. According to Stake(2006) less than 4 cases "do not show enough of the interactivity between programs and their situations" and more than 10 cases could generate an overload of information (Stake, 2006, p. 22). Therefore, eight cases in total were selected, four for each situation (B2B and B2C) from different sectors to ensure to heterogeneity. Semi-structured interviews were selected for data collection this technique is among the most important sources of evidence in case study (Yin, 2018). Marketing managers were target as interviewees to gain insights on how companies manage and evaluate the effectiveness of their SMM programmes to get a better understanding of SMM practices by companies. Questions for the interview were drawn from the literature and divided in three main themes focussing on as follows:

1 budget allocation in SMM programmes;

2 SMM goals; and

3 measures of SMM-ROI.

When appropriate the questions were unfolded in subquestions depending on the interviewee's response to the main question.

Marketing managers were invited through the internet, either by an e-mail or LinkedIn message to participate in the research. Based on the availability of the marketing managers the final sample resulted in eight cases involving companies having 
Table 3 Identification and characterization of the cases

\begin{tabular}{|c|c|c|c|c|c|}
\hline Case & Person interviewed & Sector & Size & Operation & Business model \\
\hline I & Digital marketing manager & Cork flooring and wall coverings & Large & Nationally and internationally & $\mathrm{B} 2 \mathrm{~B}$ \\
\hline II & Marketing manager & Ceramic tiles and sanitary & Small & Nationally and internationally & $\mathrm{B} 2 \mathrm{~B}$ \\
\hline III & Marketing manager & Agriculture & Large & Nationally and internationally & $\mathrm{B} 2 \mathrm{~B}$ \\
\hline IV & Sales manager & Steel solutions & Large & Nationally and internationally & $\mathrm{B} 2 \mathrm{~B}$ \\
\hline $\mathbf{V}$ & E-commerce and digital marketing manager & Fashion & Large & Nationally and internationally & $\mathrm{B} 2 \mathrm{C}$ \\
\hline VI & Digital marketing manager & Jewellery & Large & Nationally and internationally & $\mathrm{B} 2 \mathrm{C}$ \\
\hline VII & Marketing manager & Sports & Large & Nationally and internationally & $\mathrm{B} 2 \mathrm{C}$ \\
\hline VIII & CMO & Accommodation and transportation & Medium & Nationally and internationally & $\mathrm{B} 2 \mathrm{C}$ \\
\hline
\end{tabular}

distinct characteristics in terms of size, business model (B2B/ $\mathrm{B} 2 \mathrm{C}$ ), sector and country where it operates. The interviews were performed personally at the companies' headquarters and took between 20 to $30 \mathrm{~min}$. Four interviews were conducted in Portuguese and the remaining in English. Interviews were voice-recorded with the condition that the recording would only be used for the present research and could not be shared. Table 3 summarizes the characteristics of each case.

The data was analysed through qualitative content analysis based on the principle that the words may be reduced and organized into categories and subcategories in which data share the same meaning (Connaway and Powell, 2010). A coding agenda and a category system were designed and filled in by each researcher independently. Next, the classifications were compared and a final common matrix was assembled. The results were then written based on this final classification matrix by matching the topics mentioned by each company's marketing manager and comparing the results across companies within and across markets.

\subsection{Second stage}

In the second stage, quantitative research was conducted using a web-based survey drawing on the questions derived from the literature review and the ones previously used in the interviews and on the findings from the qualitative analysis of the cases. The objective of the survey was to validate the insights drawn from the cases on a larger sample.

The questionnaire consisted of 28 questions including dichotomous, multiple-choice and five-point and seven-point Likert scales. The questionnaire was pre-tested and all questions revealed to be simple, clear and understandable. The survey was deployed using google forms and the potential respondents received the link via e-mail or SM message explaining the objectives and inviting them to participate. The invitation was sent to 93 participants, but only 28 completed the questionnaire, representing a response rate of $30.1 \%$. All the respondents are responsible for SMM in their companies. In total, $13(46,4 \%)$ were from B2B companies and 15 were from B2C (53,6\%). The answers were analysed using IBM SPSS version 25 .

\section{Results}

\subsection{Interviews results}

Regarding the use of SM, the analysis indicates that the majority of the companies use at least two SM platforms. Cases $\mathrm{V}$ and VII are the ones using the higher number of SM platforms, with seven and eight, respectively. Facebook is used by all companies, followed by LinkedIn and YouTube used by six. Instagram and Twitter are used by five and Pinterest is used by four companies. Other SM platforms such as Google+, Houzz, Weibo and Spotify are only marginally used. In terms of importance, regardless of Cases III and IV, all other companies recognize the of being present in SM by rating it as important or very important. B2B companies are the ones rating low on the importance of SMM as they consider that $S M$ is not crucial to the way they do businesses. The major reasons pointed for being present in SM are the ability to promote products to a wider range of potential customers as nowadays everyone is active at least in one SM platform.

When questioned about the investment in SM, only Case IV considers that "it is not profitable". All other companies consider the financial and non-financial investment essential to obtain some gain from SM. Cases I, IV, VII are reluctant in paying for advertising, where all other cases consider paid advertising important to effectively reach consumers. For those companies investing in SM, the SMM budget is part of the global marketing budget and only the companies IV, VI and VIII disclose having a percentage allocated to SMM, ranging from $0.5 \%$ (Case IV) to $15 \%$ (Cases VI and VIII).

Except for Cases II, IV, all other companies reported having defined goals for the implementation of SMM programmes. The goals include, namely, increase visibility and brand awareness (Cases I, III, IV, V, VI and VIII); generating leads and conversion (Cases I, II, V, VII and VIII); engagement (Cases VI, VII and VIII); provide information on products (Cases II, III and V). The alignment between the company's objectives and SMM is confirmed by only $50 \%$ of the companies (Cases I, V, VII and VIII).

For the measurement of the effectiveness of the SMM programmes the companies interviewed indicate that they use mostly non-financial indicators, which is coherent with the goals stated. Table 4 presents a summary of the responses to the measurement process of SMM campaigns. Overall, the results from the cases studied revealed the existence of differences between $\mathrm{B} 2 \mathrm{~B}$ and $\mathrm{B} 2 \mathrm{C}$ cases and even within the cases with the same business model.

\subsection{Survey results}

The analysis of the cases suggests the existence of differences in the perception of efficacy and in the management of SMM programmes between B2B and B2C companies. To validate the differences, association tests were made using the data from the survey to check whether 


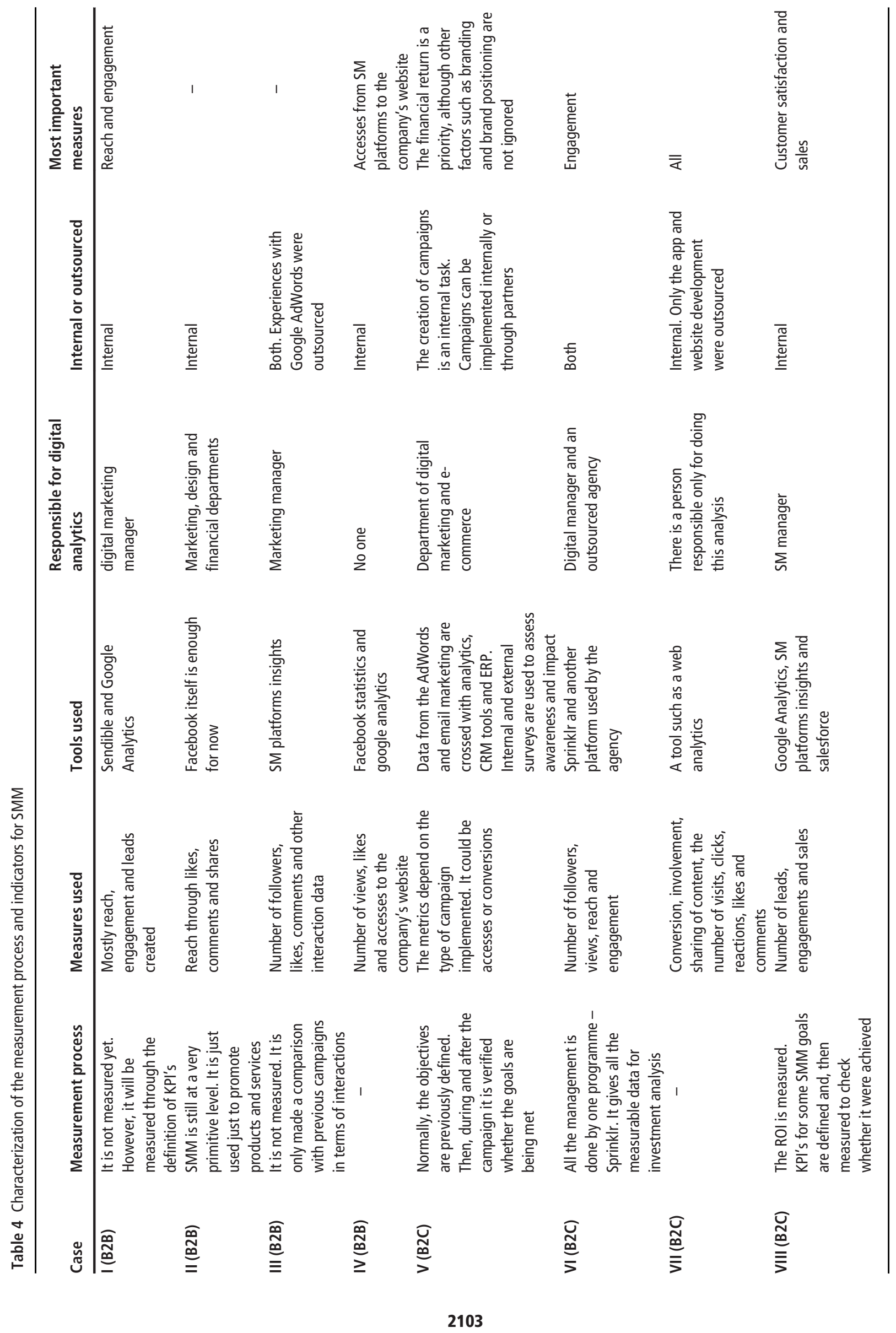


Table $5 \chi^{2}$ test for association between the business model and goals for SMM programmes

\begin{tabular}{lcccc}
\hline Indicators & Value & df & Asymptotic significance (two-sided) & Exact sig. (two-sided) \\
\hline Pearson $\chi^{2}$ & $4.182^{\mathrm{a}}$ & 1 & 0.041 \\
Continuity correction $^{\mathrm{b}}$ & 2.506 & 1 & 0.113 \\
Likelihood ratio & 4.425 & 1 & 0.035 \\
Fisher's exact test & 4.032 & 1 & 0.045 \\
Linear-by-linear association & 28 & & \\
No. of valid cases & & & \\
Notes: ${ }^{a}$ Two cells (50.0\%) have expected count less than 5. The minimum expected count is 2.79. & ${ }^{b}$ Computed only for a 2x2 table \\
\hline
\end{tabular}

being a B2B or B2C company (as the independent variable) influence the SMM behaviour. The overall null hypothesis for all tests is $\mathrm{H}_{0}=$ "there is no association between the variables". The only test, which showed a significant association at the 0.05 level was the one related to the definition of goals for SMM programmes. The $\chi^{2}$ test revealed that there is an association, although weak, between the two variables $(\mathrm{sig}=0.041)$, meaning that being a B2B or B2C company influences the definition of objectives for SMM programmes (Table 5).

For all other variables, the association tests performed did not reveal any statistically significant effect between the business model and each variable.

\section{Analysis of results}

\subsection{Budget allocation to social media marketing programmes}

Nearly all the companies interviewed (seven out of eight) agree that investment in SMM is important - not only in terms of money but also in structures, tools and human resources to manage SM channels. This investment is important to promote products and services, as well as to achieve good reach and engagement. Two B2C firms redirect some of their investment from SM platforms into reinforcing the investment in digital marketing in general but not exclusively in SMM. Just one B2B company believes that investment in SMM is not profitable for its business model. In the survey, this issue was also evaluated through a five-point Likert scale ranging from "totally disagree" to "totally agree". Globally, companies agree that the investment in SMM is important $(M=4.21)$, as it offers good opportunities to promote products $(M=3.86)$, even without considerable amounts of investment $(M=3.54)$. Nevertheless, the results also reveal some inconsistency, as the questions regarding the level of investment and commitment show low mean scores. This finding raises the question of why companies consider SMM important but do not seem willing to invest in it (Table 6).

Consistent with the results on investment, the attitude towards paid advertising in SM also diverged among the interviewees. For some companies, paid advertising is critical where others have doubts about it. Yet, they show interest in knowing more about the subject to understand

Table 6 Mean of the responses for investment in SMM programmes

\begin{tabular}{|c|c|c|c|c|}
\hline \multirow[b]{2}{*}{ Variable } & \multicolumn{2}{|c|}{$\begin{array}{c}\text { B2B } \\
n=13\end{array}$} & \multicolumn{2}{|c|}{$\begin{array}{c}\text { B2C } \\
n=15\end{array}$} \\
\hline & Mean & SD & Mean & SD \\
\hline Our company invests in SMM programmes & 2.62 & 1.04 & 2.60 & 0.99 \\
\hline There is an investment in digital marketing, but not in SMM & 2.77 & 1.09 & 2.53 & 0.92 \\
\hline Our investment in SMM is small and our publications in SM platforms are sporadic & 2.92 & 1.44 & 2.73 & 1.44 \\
\hline Without a considerable investment. Good results cannot be achieved & 3.31 & 1.03 & 3.73 & 1.03 \\
\hline Inside SM. there are interesting offers to promote products. Some of which very cheap & 3.85 & 0.80 & 3.87 & 0.74 \\
\hline The investment in SMM is very important & 4.15 & 0.69 & 4.27 & 0.70 \\
\hline
\end{tabular}

Table 7 Mean of the responses for investment in paid advertising in SMM

\begin{tabular}{|c|c|c|c|c|}
\hline \multirow[b]{2}{*}{ Variable } & \multicolumn{2}{|c|}{$\begin{array}{c}\text { B2B } \\
n=13\end{array}$} & \multicolumn{2}{|c|}{$\begin{array}{c}\text { B2C } \\
n=15\end{array}$} \\
\hline & Mean & SD & Mean & SD \\
\hline We do not invest in paid advertising in SM platforms & 2.62 & 1.39 & 2.00 & 1.20 \\
\hline Given the lack of coherence and transparency of SM platforms, SMM depends on investment & 2.92 & 0.95 & 3.33 & 0.90 \\
\hline We invest in digital advertising such as Google AdWords & 3.46 & 1.20 & 3.13 & 1.60 \\
\hline It is inevitable for those who want to communicate effectively & 3.23 & 1.09 & 4.13 & 0.92 \\
\hline Paid advertising in SM is very important & 3.62 & 0.51 & 4.20 & 0.68 \\
\hline Paid advertising in SM can be important to reach out to more people and conquer potential stakeholders & 4.46 & 0.66 & 4.00 & 1.00 \\
\hline
\end{tabular}


whether it is worth investing. The most extreme position are the ones from Cases IV and VII, expressing complete disinterest for this type of investment. The survey results on the same topic reveal that companies generally agree that paid advertising "is inevitable for those who want to communicate effectively" ( $M=3.71)$, "paid advertising in SM is very important" $(M=3.93)$ and "paid to advertise in SM can be important to reach more people and conquer potential stakeholders" $(M=4.21)$ (Table $7 /)$.

Concerning the definition of the budget allocated to SMM programmes by B2C companies, two cases indicate having well-defined budgets with specific percentages of the global marketing budget, with no deviation. For the remaining $\mathrm{B} 2 \mathrm{C}$ cases the budget allocated to SMM programmes is a part of the initial budget defined for marketing or digital marketing, without any predetermined amount. Among the B2B cases, only the manager from the Case I declared considering SMM in the overall marketing budget. The survey results strengthened this finding, as most of the respondents declared not devoting any specific percentage of the marketing budget to SMM. Almost half of the respondents (46\%) invest less than $10 \%$ of the marketing budget in SMM activities and $67.8 \%$ ( 19 out of 28 ) assume that their budgets are flexible and adjustable over time. Based upon both the interviews and the survey results, it can be noticed that there is a considerable investment in digital platforms, however not exclusively in SMM. There is also some lack of precision in the definition of the budget to allocate to SMM programmes, mostly by B2B companies. Overall, the budget for this kind of marketing programmes is flexible and it depends on specific goals. Companies also reveal some difficulties measuring the investment in SM because most of the investment is not monetary (e.g. time). Results from previous campaigns seem to be the best predictor for future investments, as it was mentioned by 15 out of the 28 surveyed companies.

\subsection{Expectations regarding budget allocation to social media marketing programmes}

When questioned about the expectation of future investment in SMM programmes, seven out of the eight cases interviewed state that an increase is almost sure. The respondent of Case VI even quantifies a yearly increase of $5 \%$ in the budget allocated to SMM. The remaining companies do not unequivocally assume an increase in the percentage of the budget allocated to SMM, but they take as granted an increase in the volume of programmes and in the human resources allocated to the management of SM, as well as an improvement in the tools used to operate it. The insights from the cases were validated by the survey results showing that $64.3 \%$ expect to increase the budget in the short term and $28.6 \%$ in the medium-long term. Only two companies $(7.1 \%)$ are not sure about making any adjustments to their investment on SMM.

\subsection{Definition of goals for social media marketing programmes}

The cases studied show that all companies have some kind of objective or goal when implementing SMM programmes, although some define them more accurately than others. For two B2C companies (Cases V and VII) the goals are defined according to each brand, product, campaign or action. The objective is to improve brand awareness, reach and engagement. Besides, there are sales goals for which companies implement specific campaigns to promote conversion. Similarly, the findings of the survey show that the primary goals for implementing SMM programmes are awareness and engagement, both with $27.6 \%$ of the responses.

Concerning planning, not all companies define these goals before implementing SMM programmes. This is the only issue where differences between B2B and B2C were statistically confirmed by the survey, meaning that the business model has implications in the definition of goals for SMM programmes. Regarding the alignment between SMM goals and the overall business objectives, the analysis of the cases suggests that the alignment is more important for $\mathrm{B} 2 \mathrm{C}$ than for $\mathrm{B} 2 \mathrm{~B}$ companies, as only one B2B stated doing it. In turn, all B2C cases state having SMM goals aligned with general business goals. Overall, the results from the survey revealed that 22 companies out of 28 declare having goals for SMM aligned with overall business objectives.

\subsection{Social media marketing return on investment measurement}

Staring at the central objective of this research for investigating how B2C and B2B companies measure the ROI of SMM programmes, the findings from the interviews suggest that some companies use simple methods for evaluating the effectiveness of SMM programmes, whereas others hardly measure the ROI in SMM programmes. Case V is the only one with a more detailed measurement process. The process starts with the definition of goals for the campaign and during and after the campaign the company continuously verify the achievement of the pre-defined goals. For this company, the results of SMM campaigns are also evaluated according to the investment, which is often adjusted in real-time according to the ROI. Other B2C cases report having defined SMM goals or KPIs and measuring the ROI of their programmes, although they did not seem to have a formal process for the evaluation. In turn, B2B cases in the sample are at a more elementary stage in the management of SMM programmes with just one case stating using KPI's in the evaluation process.

Contrary to the case analysis results, the findings from the survey reveal an equal number of $\mathrm{B} 2 \mathrm{~B}$ and $\mathrm{B} 2 \mathrm{C}$ companies $(n=$ 6 ; $\mathrm{B} 2 \mathrm{~B}=46.2 \%, \mathrm{~B} 2 \mathrm{C}=40.0 \%$ ) confirming that SMM-ROI is not measured and there is a lack of knowledge about the measures to use. The majority of the companies surveyed (B2B $n=6,46.2 \%$; B2C $n=10,66.7 \%$ ) agreed that only simple metrics are used to measure the effectiveness of SMM programmes. All metrics mentioned by companies meet the ones described in the literature review, however, some confusion can be noticed in the responses between what are SMM objectives or performance indicators and what are metrics or measures for assessing the objectives. The answers to the survey reveal that interaction-related metrics are the most relevant for both B2B and B2C companies. Surprisingly, sales (conversion) is among the less used metrics by companies, namely, by B2C companies (Figure 2).

Comprehensively, the tools used to track and analyse metrics and goals meet the ones identified in the literature review, 
Figure 2 Survey results on the metrics used to evaluate the effectiveness of SMM programmes

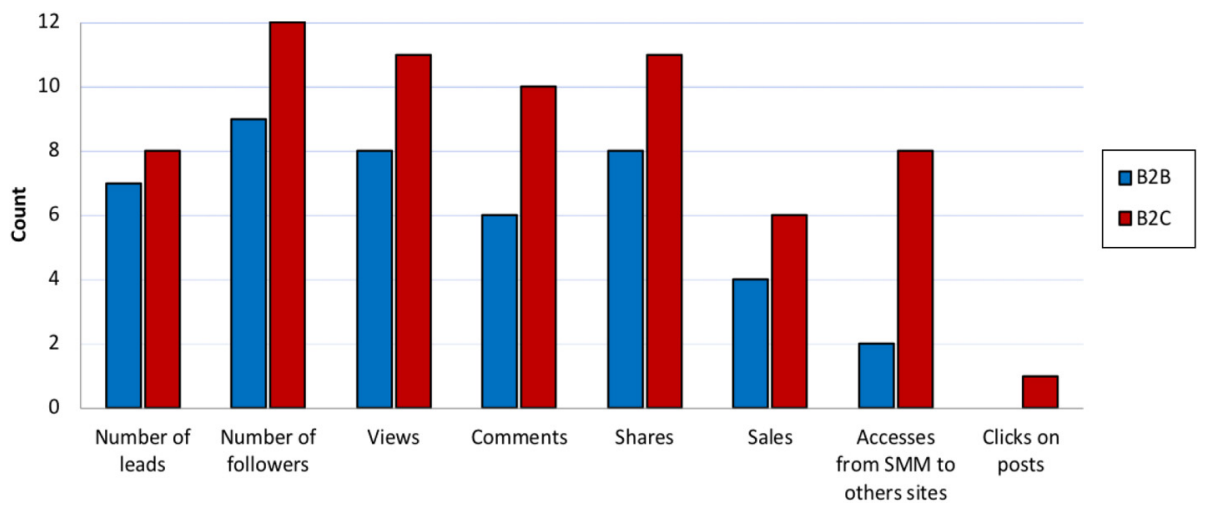

namely, web analytics tools such as Google Analytics, SM platforms specific analytics and surveys. Not surprisingly the interviews suggest that companies with a more advanced SMM-ROI measurement model such as Case V, use a higher number and more sophisticated set of tools than cases with a more basic ROI measurement process. The person responsible for making the analysis also varies according to the company's organizational structure. All B2C companies have people working specifically in the digital area such as digital or SMM managers, wherein among $\mathrm{B} 2 \mathrm{~B}$ companies just one has a digital marketing manager who administers SM analysis. For the remaining cases, it is observed that companies place less importance in SMM and for that do not have specific departments and people allocated to SM activities. Even though all companies sustain that they execute at least part of the digital analysis internally. The survey results also confirm that digital analysis is mostly carried out internally (B2B $n=11$, $84.6 \%$; B2C $n=12,80 \%)$.

\subsection{Importance of financial measures}

Regarding whether financial measures are important in SMM and even though none of the companies interviewed has a precise ROI measurement model, it appears that measures linked to revenue are more important for B2C, as no B2B company has identified financial metrics as the most important. This finding is consistent with the literature suggesting that financial measures such as conversion, are more important in companies that sell directly to the end customer or through an online channel. Furthermore, more important than financial metrics B2C companies seem to be mainly concerned with accesses from SM platforms to their websites, reach, engagement, awareness and customer satisfaction, as they rate them as the most important measures and metrics. According to two B2C companies, engagement is the only way to understand if the content produced is interesting and adequate to ensure greater interaction between the customer and the brand. Contrarily, B2B companies interviewed did not reveal concern to metrics related to revenue. The few metrics in which these companies expressed interest are the ones related to awareness, engagement and reach. This result is consistent with the findings by Michaelidou et al. (2011) and Siamagka et al. (2015) that most of the B2B companies only pay attention to interaction when evaluating the efficacy of their SM actions. The results from the survey reinforce the conclusions drawn from the analysis of interviews by showing that interaction measures are the most important for both B2B and B2C companies (Figure 3).

\section{Conclusions}

The objectives of this research were to compile and understand and compare the measures used by B2C and B2B SM

Figure 3 Most important measures of ROI in SMM programmes

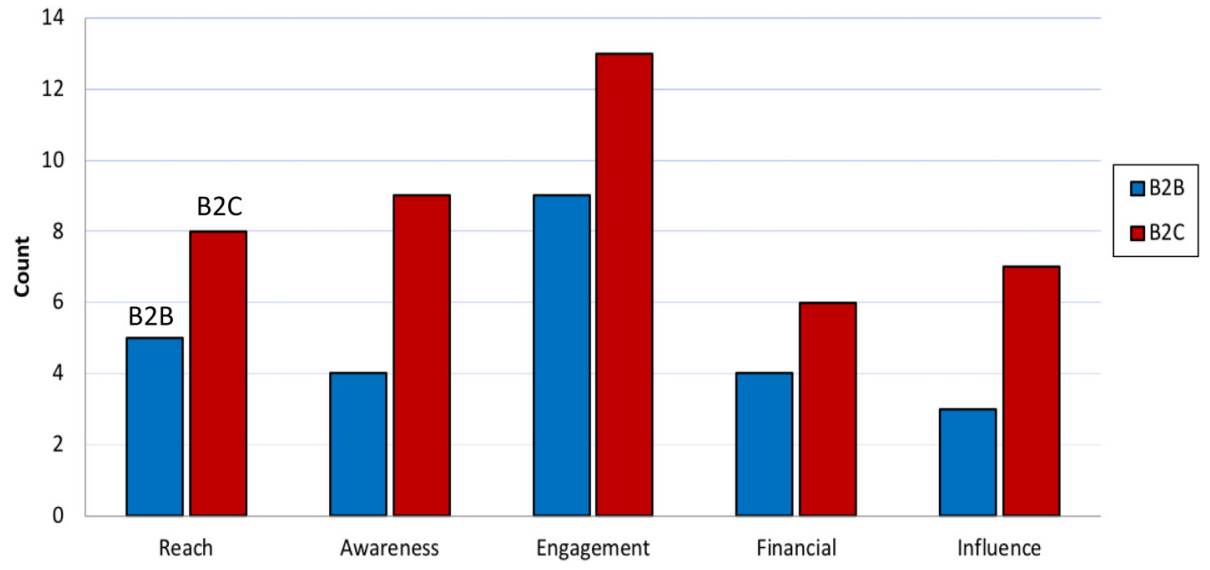


managers to evaluate the SM presence and investigate they define and allocate budgets to SMM campaigns. The literature review conducted showed that there are a plethora of measures used to evaluate the performance and success of SMM programmes, mostly non-financial. The current finding shows that the measures used by the companies are related to objectives of awareness, engagement, reach and less the financial returns, which is in accordance with the measures identified in the literature. However, contrary to what was expected, financial measures are not the most important, even for B2C companies. The financial measures seem to be relegated to a secondary role when evaluating SMM activities, most probably due to difficulties in quantifying the direct revenues generated by campaigns. This is an important finding, suggesting that if a way is found to consolidate the link between SMM activities and sales revenues companies will be more predisposed to adopt and use financial measures. Under the current conditions, it seems that marketing managers believe that despite awareness, engagement, reach and influence, it cannot be easily converted into financial results they are a good proxy for financial return. Nevertheless, engagement and awareness are considered the most important measures of ROI for both types of companies and financial measures are considered the less important, suggested that companies do not depend on financial indicators to evaluate SMM programmes, which may be regarded as a constraint to the adoption of SMM be companies. These insights are consistent with the survey results on the metrics used to evaluate the effectiveness of SMM programmes, which indicate the number of followers and shares as the metrics most used.

These findings help conclude that many companies are still at an immature level concerning the level of knowledge about the ROI of SMM programmes, as the most-used metrics identified are as follows: accesses, number of leads, followers, visits, clicks, likes, comments, sharing of contents and extra figures on interaction. These results also suggest that B2B companies may be positioned in the initial stages of the social marketing capability maturity model proposed by Wang et al. (2017). This lack of maturity may explain why investment in SMM programmes is not seen as a priority by B2B companies despite they consider it important. As a logical consequence, for many companies, the measurement of the ROI is not even considered. In fact, based on the results of this study SMM is seen more as a communication and relationship instrument than a sales-promotion tool, for both $\mathrm{B} 2 \mathrm{~B}$ and $\mathrm{B} 2 \mathrm{C}$ companies but especially for B2B. The analysis of the cases and the findings from the survey reveal the underdeveloped state of the ROI measurement process associated with SMM. B2C cases, which may have online commerce and could more easily measure the SMM benefits, are the ones showing a more developed state in ROI evaluation. Some of them already define specific objectives, have more refined measures of ROI, use more tools to track metrics and cognitively assume that SMM-ROI can and should be measured.

Overall, the current findings confirm that despite companies recognising the importance of SM the topic of SMM-ROI evaluation is still surrounded by a large degree of uncertainty. Many companies, both from B2C or M2B markets do not pay attention to the ROI of their SMM programmes, which seems rather strange in pure business logic. In fact, the majority of the companies rate SMM as important or very important, invest in it, but in practice do not evaluate the returns they get from the investments in such type of programmes. Although the cases studied show that companies operating directly with the final consumer in the B2C market are a bit more developed regarding the evaluation of the effectiveness of SMM programmes. The same happens with budget allocation, which the majority expects will grow in the future. However, companies display difficulty when having to quantify the increase, as only some B2C companies define a specific percentage of the marketing budget for SMM and B2B companies do not seem to care with how much they should allocate to SMM. In general, it can be concluded that a large proportion of companies are still allocating just a marginal part of their marketing budget to SM and in many cases, there is low autonomy for SM managers to take decisions, as they are dependent of the chief marketing officer (CMO).

Despite the common belief that SM presence is cheap or even free, an interesting insight from the results is that many marketing managers understand that the efforts and investment in SM have to be directed to create specific structures and to hire and training human resources, especially for this function. Overall, for B2C and B2C firms, SMM seems to be an important communication tool to promote products and brands and to generate awareness and build close relationships with customers, but not the preferred method to increase sales. In fact, B2B companies seem to be more conscious of the importance of investing in SMM to effectively communicate with stakeholders and achieve good SMM results. Despite having multiple reasons to invest in SMM programmes, the majority of the companies do not measure the effectiveness of the presence on SM platforms and, in many cases, there is no professional responsible for and specialized in digital marketing. Even though, it seems that B2C companies are a step forward in the ROI measurement of SMM programmes.

At a theoretical level, the findings of this study extend the almost inexistent literature about the measurement of ROI for SMM programmes in $\mathrm{B} 2 \mathrm{C}$ and $\mathrm{B} 2 \mathrm{~B}$ markets. The current outlook is a relevant advance into the understanding of how firms are evaluating the effectiveness of the investment in SMM programmes. The current contributions are important to the body of knowledge as they provide an assessment of the measures used to evaluate SMM programmes. Additionally, the study provides a comparison of how B2B and B2C use the several metrics available and allocate resources to the management of SMM. The clear and detailed outlook provided of how B2B and B2C companies approach SMM strategies and measure the ROI, as well as the comparison between company practices contributes to the available knowledge and provides a base to promote additional theory development, as this is an area where the available research is scarce.

\section{Managerial implications}

This research provides valuable information about what is actually happening in the market, and therefore, it offers important insights for managers on how to measure and evaluate SMM. Through the identification of the several measures used to evaluate SMM programmes, this study offers a basis to B2B and B2C SM managers for understanding the available options for 
measuring the return of SMM campaigns and to do it in a more structured and professional way. The findings also point that B2B companies may profit from partnering with non-competing B2C companies as the later are in a superior stage of development in what concerns SMM management and evaluation.

Another important insight deals with the importance of integrating SMM activities in the company marketing plan, and consider it when setting the overall marketing budget. As this investigation reveals differences in the ways of approaching SM by $\mathrm{B} 2 \mathrm{C}$ and $\mathrm{B} 2 \mathrm{~B}$ firms the findings may serve as an incentive for marketing managers to learn more about SMM and implement new practices, namely, in the ones connected with investment, ROI evaluation and measures of SMM effectiveness. Findings way of linking SMM with sales seems an important step to promote the willingness of companies to evaluate SMM-ROI and find and adopt financial and nonfinancial measures for evaluating it.

\section{Research limitations and future directions}

The main limitation of this study is that it cannot be generalized to the population. Due to the complex and sensitive nature of the subject, more research is needed focussed on providing additional evidence from a larger sample of B2B and B2C organizations to allow the extension of the finding to the population as the non-probabilistic nature and size of the current sample impose limitations to the interpretation and extension of the results. Additionally, the current study does not provide an answer to the reasons behind companies' behaviour in terms of measurement of SMM activities. As answering the "why" question is vital it should be addressed by future research. Another interesting issue to explore in future research is to try to understand what the firm's characteristics predict the importance and level of effort placed in SMM, as the findings have shown different approaches among companies with the same business model (B2B and B2C). Future research should also focus on understanding the barriers to ROI measurement in SMM programmes, especially in B2B firms and the reasons for the low importance generally placed on financial measures.

\section{References}

Andersson, S. and Wikström, N. (2017), "Why and how are social media used in a B2B context, and which stakeholders are involved?", Fournal of Business $\mathcal{E}$ Industrial Marketing, Vol. 32 No. 8, pp. 1098-1108.

Atanassova, I. and Clark, L. (2015), "Social media practices in SME marketing activities: a theoretical framework and research agenda", fournal of Customer Behaviour, Vol. 14 No. 2, pp. 163-183.

Bartholomew, D. (2009), "Measuring influence in social media”, available at: https://metricsman.wordpress.com/ 2009/06/04/measuring-influence-in-social-media/ (accessed 26 December 2019).

Bartholomew, D. (2010), "Relief from your social media ROI angst”, available at: https://metricsman.wordpress.com/ 2010/02/25/relief-from-your-social-media-roi-angst/ (accessed 26 December 2019).
Bartholomew, D. (2011), "Social media measurement 2011: five things to forget and five things to learn", available at: https://metricsman.wordpress.com/2010/12/30/social-mediameasurement-2011-five-things-to-forget-and-five-things-tolearn/ (accessed 15 August 2019).

Baxter, P. and Jack, S. (2008), "Qualitative case study methodology: study design and implementation for novice researchers", The Qualitative Report, Vol. 13 No. 4, pp. 544-559.

Bernard, M. (2016), "The impact of social media on the B2B CMO”, Fournal of Business $\&$ Industrial Marketing, Vol. 31 No. 8, pp. 955-960.

Blanchard, O. (2009), "Olivier Blanchard basics of social media ROI", available at: www.slideshare.net/thebrandbuilder/ olivier-blanchard-basics-of-social-media-roi (accessed 26 December 2019).

Blanchard, O. (2011), Social Media ROI: Managing and Measuring Social Media Efforts in Your Organization, Pearson Education, Boston.

Bocconcelli, R., Cioppi, M. and Pagano, A. (2017), "Social media as a resource in SMEs' sales process", fournal of Business E Industrial Marketing, Vol. 32 No. 5, pp. 693-709.

Bolat, E., Kooli, K. and Wright, L.T. (2016), "Businesses and mobile social media capability", fournal of Business $\mathcal{E}$ Industrial Marketing, Vol. 31 No. 8, pp. 971-981.

Bughin, J. and Chui, M. (2010), "The rise of the networked enterprise: web 2.0 finds its payday", McKinsey Quarterly, Vol. 19 No. 12, pp. 1-9.

Campbell, C. (2011), "Social analytics tools for measuring the impact of your social media marketing campaign", available at: www.lakeshorebranding.com/company/blog/social-analyticstools-for-measuring-the-impact-of-your-social-mediamarketing-campaign/ (accessed 26 December 2019).

Carr, C.T. and Hayes, R.A. (2015), "Social media: defining", Atlantic Fournal of Communication”, Vol. 23 No. 1, pp. 46-65.

Coleman, J.E. and Heriot, K.C. (2014), "Social media effectiveness for small businesses: concept and measurement", fournal of Business and Economics, Vol. 5 No. 6, pp. 769-774.

Colicev, A., Malshe, A., Pauwels, K. and O’Connor, P. (2018), "Improving consumer mindset metrics and shareholder value through social media: the different roles of owned and earned media", fournal of Marketing, Vol. 82 No. 1, pp. 37-56.

Connaway, L.S. and Powell, R.R. (2010), Basic Research Methods for Librarians, 5th ed., Libraries Unlimited, Santa Barbara, Denver, Oxford.

Culnan, M.J., McHugh, P.J. and Zubillaga, J.I. (2010), “How large U.S. companies can use twitter and other social media to gain business value", MIS Quarterly Executive, Vol. 9 No. 4, pp. 243-259.

Cytron, S.H. (2013), " 5 Lessons to learn about social media", Main Street Practitioner, pp. 16-18.

Dorflinger, T. (2011), "Social media measurement: how to legitimize the effort in online communication", Thesis Submitted to the University of Applied Sciences $\mathrm{FH}$ Joanneum Graz.

Etlinger, S. and Li, C. (2011), "A framework for social analytics, altimeter group", available at: https:/faculty.darden. virginia.edu/gbus8630/doc/altimetersocialanalytics081011final110810105257-phpapp01.pdf 
Fieler, B. (2017), "Using metrics to measure social media success at your firm", Accounting Today, available at: www. accountingtoday.com/opinion/using-metrics-to-measuresocial-media-success-at-your-firm (accessed 15 August 2019).

Filisko, G.M. (2011), "Social media or snake oil", $A B A$ Fournal, Vol. 97 No. 1, pp. 26-27.

Fisher, T. (2009), "ROI in social media: a look at the arguments", Fournal of Database Marketing \& Customer Strategy Management, Vol. 16 No. 3, pp. 189-195.

Gilfoil, D.M. and Jobs, C. (2012), "Return on investment for social media: a proposed framework for understanding, implementing, and measuring the return", fournal of Business E Economics Research (FBER), Vol. 10 No. 11, pp. 637-650.

Gillin, P. (2010), "Making the ROI case for social media”, Ad Age, available at: http://adage.com/article/btob/making-roicase-social-media/279614/ (accessed 26 December 2019).

Hall, L. and Hume, C. (2011), "Why numbers, invites and visits are not enough: evaluating the user experience in social eco-systems", SOTICS 2011: The First International Conference on Social Eco-Informatics, pp. 8-13.

Hanna, R., Rohm, A. and Crittenden, V.L. (2011), "We're all connected: the power of the social media ecosystem", Business Horizons, Vol. 54 No. 3, pp. 265-273.

Headley, M. (2015), Social Media Marketing Trends: A 2015 Survey and Report on Social Media Marketing Practices and Software Usage, available at: http:/get.simplymeasured. com/rs/simplymeasured2/images/2015SocialMarketing TrendsReportTrustRadius.pdf

Hennig-Thurau, T., Malthouse, E.C., Friege, C., Gensler, S., Lobschat, L., Rangaswamy, A. and Skiera, B. (2010), "The impact of new media on customer relationships", fournal of Service Research, Vol. 13 No. 3, pp. 311-330.

Hewett, K., Rand, W., Rust, R.T. and Van Heerde, H.J. (2016), "Brand buzz in the echoverse", fournal of Marketing, Vol. 80 No. 3, pp. 1-24.

Hoffman, D.L. and Fodor, M. (2010), "Can you measure the ROI of your social media marketing?", MIT Sloan Management Review, Vol. 52 No. 1, pp. 41-49.

Hoffman, D.L. and Novak, T. (2012), Why do people use social media? Empirical findings and a new theoretical framework for social media goal pursuit?, Empirical Findings and a New Theoretical Framework for Social Media Goal Pursuit (Fanuary 17), pp. 1-33, available at: https://dx.doi.org/ $10.2139 /$ ssrn. 1989586

Holloman, C. (2014), The Social Media MBA Guide to ROI: How to Measure and Improve Your Return on Investment, John Wiley \& Sons, New York, NY.

Huotari, L., Ulkuniemi, P., Saraniemi, S. and Mäläskä, M. (2015), "Analysis of content creation in social media by B2B companies”, fournal of Business \& Industrial Marketing, Vol. 30 No. 6, pp. 761-770.

Iankova, S., Davies, I., Archer-Brown, C., Marder, B. and Yau, A. (2019), "A comparison of social media marketing between B2B, B2C and mixed business models", Industrial Marketing Management, Vol. 81, pp. 169-179.

Jackson, D. (2017), "Ultimate guide to measuring social media ROI”, available at: https://sproutsocial.com/insights/socialmedia-roi-guide/ (accessed 26 December 2019).
Jussila, J.J., Kärkkäinen, H. and Aramo-Immonen, H. (2014), "Social media utilization in business-to-business relationships of technology industry firms", Computers in Human Behavior, Vol. 30, pp. 606-613.

Kaske, F., Kügler, M. and Smolnik, S. (2012), "Return on investment in social media - does the hype pay off? Towards an assessment of the profitability of social media in organizations", 45th Annual Hawaii International Conference on System Sciences, pp. 3898-3907.

Keinänen, H. and Kuivalainen, O. (2015), "Antecedents of social media B2B use in an industrial marketing context: customers' view", fournal of Business $\mathcal{E}$ Industrial Marketing, Vol. 30 No. 6, pp. 711-722.

Kietzmann, J.H., Hermkens, K., McCarthy, I.P. and Silvestre, B.S. (2011), "Social media? Get serious! Understanding the functional building blocks of social media", Business Horizons, Vol. 54 No. 3, pp. 241-251.

Kumar, V. and Mirchandaniand, R. (2012), "Increasing the ROI of social media marketing", MIT Sloan Management Review, Vol. 54 No. 1, pp. 55-63.

Lacka, E. and Chong, A. (2016), "Usability perspective on social media sites' adoption in the B2B context", Industrial Marketing Management, Vol. 54, pp. 80-91.

Lake, C. (2009), "35 Social media KPIs to help measure engagement", Econsultancy, available at: https:// econsultancy.com/blog/4887-35-social-media-kpis-tohelp-measure-engagement (accessed 30 November 2019).

Lashgari, M., Sutton-Brady, C., Solberg Søilen, K. and Ulfvengren, P. (2018), "Adoption strategies of social media in B2B firms: a multiple case study approach", fournal of Business E Industrial Marketing, Vol. 33 No. 5, pp. 730-743.

Mangiuc, D.M. (2009), "Measuring web 2.0 efficiency", Annales Universitatis Apulensis Series Oeconomica, Vol. 11 No. 8, pp. 74-88.

Michaelidou, N., Siamagka, N.T. and Christodoulides, G. (2011), "Usage, barriers and measurement of social media marketing: an exploratory investigation of small and medium B2B brands", Industrial Marketing Management, Vol. 40 No. 7, pp. 1153-1159.

Murdough, C. (2009), "Social media measurement: it's not impossible", fournal of Interactive Advertising, Vol. 10 No. 1, pp. 94-99.

Nair, M. (2011), "Understanding and measuring the value of social media", fournal of Corporate Accounting \& Finance, Vol. 22 No. 3, pp. 45-51.

Owyang, J. (2010), "Framework: the social media ROI pyramid", Altimeter Group, available at: www.webstrategist.com/blog/2010/12/13/framework-the-social-mediaroi-pyramid/ (accessed 12 August 2019).

Paul, B., Pooja, M., Jennifer, B., Jiangmei, C. and Bruce, W. (2012), "The impact of social media usage on consumer buying behavior", Advances in Management, Vol. 5 No. 1, pp. 14-22.

Pauwels, K., Ambler, T., Clark, B., LaPointe, P., Reibstein, D., Skiera, B., Wierenga, B. and Wiesel, T. (2009), "Dashboards \& marketing: why, what, how and which research is needed?", Fournal of Service Research, Vol. 12 No. 2, pp. 175-189. 
Peters, K., Chen, Y., Kaplan, A.M., Ognibeni, B. and Pauwels, K. (2013), "Social media metrics - a framework and guidelines for managing social media”, foumal of Interactive Marketing, Vol. 27 No. 4, pp. 281-298.

Powell, G.R., Groves, S.W. and Dimos, J. (2011), ROI of Social Media: How to Improve the Return on Your Social Marketing Investment, John Wiley \& Sons (Asia) Pte. Lda, Singapore.

Ray, A. Riley, E. Wise, J. and Elliott, N. (2010), "The ROI of social media marketing", Interactive Marketing Professionals.

Shaltoni, A.M. (2017), "From websites to social media: exploring the adoption of internet marketing in emerging industrial markets", fournal of Business \& Industrial Marketing, Vol. 32 No. 7, pp. 1009-1019.

Siamagka, N., Christodoulides, G., Michaelidou, N. and Valvi, A. (2015), "Determinants of social media adoption by B2B organizations", Industrial Marketing Management, Vol. 51, pp. 89-99.

Simons, H. (2009), Case Study Research in Practice, SAGE Publications, London.

Stake, R.E. (2006), Multiple Case Study Analysis, The Guilford Press, Vol. 14, Guilford Press, New York, NY, doi: 10.1007/ s40315-013-0039-6.

Statista (2017), "Number of social media users worldwide 2010-2020", available at: www.statista.com/statistics/278414/ number-of-worldwide-social-network-users/

Statista (2020), "Social media advertising worldwide", available at: www.statista.com/outlook/220/100/social-mediaadvertising/worldwide (accessed 31 March 2020).

Stelzner, M.A. (2016), Social Media Marketing Industry Report, Social Media Examiner, available at: www. socialmediaexaminer.com/social-media-marketing-industryreport-2016/

Sterne, J. (2010), Social Media Metrics: How to Measure and Optimize Your Marketing Investment, John Wiley \& Sons, NJ.

Stokes, R. (2013), EMarketing: The Essential Guide to Marketing in a Digital World, 5th ed., Quirk Education Pty (Ltd).

Thomas, G. (2015), How to Do Your Case Study, 2nd ed., SAGE Publications, Los Angeles.

Turner, J. (2010), "HOW to: calculate the ROI of your social media campaign".
Turner, J. and Shah, R. (2014), How to Make Money with Social Media: An Insider's Guide on Using New and Emerging Media to Grow Your Business, 2nd ed., Pearson Education, London.

Tuten, T.L. (2008), Advertising 2.0: Social Media Marketing in a Web 2.0 World, 1st ed., Praeger Publishers, Westport.

Tuten, T.L. and Solomon, M.R. (2014), Social Media Marketing, 2nd ed., SAGE Publications, London.

Vlachvei, A. and Notta, O. (2015), "Understanding social media ROI in SMEs IRC-2015 understanding social media ROI in SMEs", Proceedings of International Organization for Research and Development -IRC2015, pp. 1-6.

Voorveld, H.A.M., van Noort, G., Muntinga, D.G. and Bronner, F. (2018), "Engagement with social media and social media advertising: the differentiating role of platform type", fournal of Advertising, Vol. 47 No. 1, pp. 38-54.

Wang, Y., Rod, M., Ji, S. and Deng, Q. (2017), "Social media capability in B2B marketing: toward a definition and a research model", fournal of Business E Industrial Marketing, Vol. 32 No. 8, pp. 1125-1135.

Weinberg, B.D. and Pehlivan, E. (2011), "Social spending: managing the social media mix", Business Horizons, Vol. 54 No. 3, pp. 275-282.

Yin, R.K. (2018), "Case study research and applications: design and methods", Sixth Edit, SAGE Publications, Thousand Oaks, CA.

Zeithaml, V.A., Jaworski, B.J., Kohli, A.K., Tuli, K.R., Ulaga, W. and Zaltman, G. (2020), "A theories-in-use approach to building marketing theory", fournal of Marketing, Vol. 84 No. 1, pp. 32-51.

Zhang, C.B. and Li, Y. (2019), "How social media usage influences B2B customer loyalty: roles of trust and purchase risk", Fournal of Business \& Industrial Marketing, Vol. 34 No. 7, JBIM-07-2018-0211.

Zheng, D., Chen, H., Lusch, R. and Li, S.H. (2010), "Social media analytics and intelligence", IEEE Intelligent Systems, Vol. 25 No. 6, pp. 13-16.

\section{Corresponding author}

Susana Costa e Silva can be contacted at: ssilva@porto.ucp. $\mathrm{pt}$ 